\title{
ANALISIS PEMAHAMAN KONSEP PELUANG SISWA SMP DITINJAU DARI TEORI APOS
}

\author{
Bella Tika Pramesti ${ }^{1}$, Helti Lygia Mampouw ${ }^{2}$ \\ ${ }^{1,2}$ Universitas Kristen Satya Wacana, Jalan Diponegoro No.52-60 Salatiga \\ 202016009@student.uksw.edu
}

\begin{abstract}
The study of probability needs a combination of logical thinking and experience in daily life. The purpose of this qualitative descriptive research is to describe the way of students thinking based on the analysis results toward the understanding of the probability concept of junior high school students based on stages of APOS (action, process, object, and scheme). The subjects of this research are three junior high school students grade IX by using purposive technique with different mathematics ability: high, medium, low. The main instrument of research is the researcher and two questions of mathematics ability test questions and interview guidelines as the supporting instruments. The results of the research showed that the action of the three subjects knew the first action to solve the probability questions and were able to explain verbally about the meaning of questions test. The high and medium capable subjects explained it as detail as possible while the low capable subject explained it simply. The high and medium capable subject achieved the process stage and the high capable subject used a table to complete the test. On the object stage, the high and medium capable subjects answered the questions based on their own way. The high capable subject solved the questions by using the methods that have been learnt and the medium capable subject preferred to simplify it. The high and medium capable subjects were able to develop the concept that has been learned on the scheme stage.
\end{abstract}

Keywords: Probability, APOS

\begin{abstract}
Abstrak
Belajar materi peluang membutuhkan kombinasi logika berpikir dan pengalaman dalam kehidupan sehari-hari. Penelitian deskriptif kualitatif ini bertujuan mendeskripsikan cara berpikir siswa berdasarkan hasil analisis pemahaman konsep peluang siswa SMP yang ditinjau dari urutan aksi, proses, objek, dan skema. Subjek terdiri dari 3 siswa kelas IX SMP yang diambil secara purposive dan memiliki kemampuan yang berbeda-beda masingmasing tinggi, sedang, dan rendah. Instrumen penelitian utama adalah peneliti dibantu instrumen pendukung berupa 2 soal pada tes kemampuan matematika dan pedoman wawancara. Hasil penelitian menunjukkan aksi dari ketiga subjek yaitu mengetahui tindakan awal untuk menyelesaikan soal peluang dan mampu menjelaskannya secara verbal maksud dari soal tes yang diberikan. Subjek berkemampuan matematika tinggi dan sedang menjelaskan secara terperinci sedangkan subjek berkemampuan matematika rendah menjelaskan secara sederhana. Subjek berkemampuan matematika tinggi dan sedang mencapai tahap proses, subjek berkemampuan matematika tinggi menggunakan tabel dalam penyelesaiannya. Pada tahap objek subjek berkemampuan matematika tinggi dan sedang menyelesaikan soal tes dengan caranya masing-masing yaitu subjek berkemampuan matematika tinggi menyelesaikan soal dengan metode yang dipahaminya dan subjek berkemampuan matematika sedang menyelesaikan dengan menyederhanakannya. Skema yang dimiliki subjek berkemampuan tinggi dan sedang yaitu mampu mengembangkan konsep yang telah mereka pelajari.
\end{abstract}

Kata Kunci: Peluang, APOS

\section{PENDAHULUAN}

Pemahaman merupakan kemampuan setiap orang supaya dapat memahami makna dari sesuatu yang dipelajari, dinyatakan dengan mengubah data yang disajikan dalam suatu bentuk tertentu ke dalam bentuk yang berbeda (Sudaryono, 2012). Konsep dalam matematika saling berhubungan, 
konsep yang sederhana pun memiliki peranan sebagai konsep prasyarat untuk menuju pemahaman konsep yang lebih kompleks (Matitaputty, 2016). Pemahaman konsep merupakan penguasaan dalam materi pembelajaran ketika siswa tidak hanya mengetahui tapi mampu menjelaskan kembali sebuah konsep dengan lebih mudah dan dapat melakukannya (Rosmawati, 2008). Pemahaman konsep dapat diartikan sebagai karakteristik seseorang dalam memaknai suatu pemahaman dengan pikiran dan pandangan yang benar. Tabel 1 menunjukkan indikator pemahaman konsep.

\section{Tabel 1.}

Indikator Pemahaman Konsep

\begin{tabular}{|c|c|}
\hline $\begin{array}{c}\text { Kerangka } \\
\text { Kerja APOS }\end{array}$ & Indikator Pemahaman Konsep \\
\hline Aksi & $\begin{array}{l}\text { 1. Mampu menjelaskan secara verbal mengenai apa yang telah dicapainya. } \\
\text { 2. Mampu menyajikan situasi matematika kedalam berbagai cara serta } \\
\text { mengetahui perbedaan. }\end{array}$ \\
\hline Proses & $\begin{array}{l}\text { 1.Mampu menjelaskan secara verbal mengenai apa yang telah dicapainya. } \\
\text { 2.Mampu menyajikan situasi matematika kedalam berbagai cara serta } \\
\text { mengetahui perbedaan. } \\
\text { 3. Mampu mengklasifikasikan objek-objek berdasarkan dipenuhi atau tidaknya } \\
\text { persyaratan yang membentuk konsep tersebut. }\end{array}$ \\
\hline Objek & $\begin{array}{l}\text { 1.Mampu menerangkan secara verbal mengenai apa yang telah dicapainya. } \\
\text { 2.Mampu menyajikan situasi matematika kedalam berbagai cara serta mengetahui } \\
\text { perbedaan. } \\
\text { 3.Mampu mengklasifikasikan objek-objek berdasarkan dipenuhi atau tidaknya } \\
\text { persyaratan yang membentuk konsep tersebut. } \\
\text { 4.Mampu menerapkan antar konsep dan prosedur. } \\
\text { 5.Mampu menerapkan konsep secara algoritma. }\end{array}$ \\
\hline Skema & $\begin{array}{l}\text { 1.Mampu menerangkan secara verbal mengenai apa yang telah dicapainya. } \\
\text { 2.Mampu menyajikan situasi matematika kedalam berbagai cara serta } \\
\text { mengetahui perbedaan. } \\
\text { 3.Mampu mengklasifikasikan objek-objek berdasarkan dipenuhi atau tidaknya } \\
\text { persyaratan yang membentuk konsep tersebut. } \\
\text { 4.Mampu menerapkan antar konsep dan prosedur. } \\
\text { 5.Mampu menerapkan konsep secara algoritma. } \\
\text { 6.Mampu mengembangkan konsep yang telah dipelajari }\end{array}$ \\
\hline
\end{tabular}

Peluang merupakan suatu ukuran yang menunjukkan seberapa besar kemungkinan di antara keseluruhan peristiwa yang akan terjadi. Di sekolah, materi peluang diberikan mulai kelas VIII SMP semester 2. Materi peluang merupakan materi yang dekat dengan pengalaman sehari-hari karena menggunakan banyak contoh pada konteks yang sudah dikenal siswa. Namun demikian, hasil belajar matematika umumnya masih jauh dari yang diharapkan. Tabel 2 menampilkan daya serap keempat aspek matematika di mana materi statistika dan peluang memiliki penguasaan tertinggi sebesar 
55,60\%. Meskipun persentase daya serap materi statistika dan peluang lebih tinggi daripada ketiga materi lainnya tetapi daya serap 55,60\% tergolong masih rendah.

Tabel 2

Hasil Persentase Daya Serap Ujian Nasional 2018/2019

\begin{tabular}{|c|l|c|}
\hline No & \multicolumn{1}{|c|}{ Materi } & Persentase daya serap \\
\hline 1 & Bilangan & 39,71 \\
\hline 2 & Aljabar & 51,24 \\
\hline 3 & Geometri dan pengukuran & 42,27 \\
\hline 4 & Statistika dan peluang & 55,60 \\
\hline
\end{tabular}

Diadaptasi dari Kemendikbud 2018 (https://hasilun.puspendik.kemdikbud.go.id).

Aspek statistika dan peluang pada ujian nasional tahun 2018/2019 terdiri dari 6 indikator. Tabel 2 menampilkan indikator materi statistika dan peluang, yakni 4 indikator statistika dan 2 indikator peluang. Dari kedua indikator peluang tersebut, menghitung peluang data pengundian dadu memiliki tingkat penguasaan materi lebih rendah yakni sebesar $46,53 \%$.

Tabel 3

Indikator Statistika Dan Peluang Berdasarkan SKL (Standar Kompetensi Kelulusan) Ujian Nasional $2018 / 2019$

\begin{tabular}{|c|l|c|}
\hline No & \multicolumn{1}{|c|}{ Indikator } & $\begin{array}{c}\text { Persentase } \\
\text { Daya Serap }\end{array}$ \\
\hline 1 & Menentukan median/modus data tunggal & 99,69 \\
\hline 2 & Menyelesaikan masalah unsur-unsur diagram lingkaran & 59,34 \\
\hline 3 & Menyelesaikan masalah aplikasi pemusatan data & 46,05 \\
\hline 4 & Menghitung peluang data pengundian dadu & 46,53 \\
\hline 5 & Menyelesaikan masalah peluang dalam kehidupan sehari-hari & 61,03 \\
\hline 6 & Menganalisis masalah yang berhubungan dengan pemusatan data & 20,96 \\
\hline
\end{tabular}

Diadaptasi dari Kemendikbud 2018 (https://hasilun.puspendik.kemdikbud.go.id).

Pemahaman konsep yang tidak kuat akan menyebabkan kesalahan-kesalahan pada jenjang berikutnya. Namun berbeda dengan pendapat tersebut, menyelesaikan masalah peluang dalam kehidupan sehari-hari justru memiliki daya serap yang lebih tinggi, yakni sebesar $61,03 \%$. Adanya penguasaan mengaplikasikan konsep peluang yang lebih baik daripada pemahaman konsep peluang itu sendiri mendorong perlunya kajian tentang cara berpikir siswa dalam memahami dan mengimplementasikan konsep peluang. Pernyataan tersebut juga didukung oleh (Ningsih, 2016) yaitu masih kurangnya kemampuan menyajikan konsep dalam bentuk representasi matematika. Sholihah dan Mubarok (2016) menyatakan bahwa siswa belum mampu menggunakan konsep serta prosedur dalam menyelesaikan soal yang berkaitan dengan kehidupan sehari-hari dan belum mampu menyelesaikan model matematika yang telah terbentuk dengan menggunakan aksi, proses, objek, dan skema. 
Cara berpikir siswa tentang peluang dapat ditelusuri dengan mengamati tahap-tahap perkembangan skema kognitif siswa tentang peluang. Salah satu teori yang dapat menjelaskan adalah teori aksi, proses, objek, dan skema (APOS). Teori APOS digunakan untuk memahami suatu mekanisme abstraksi reflektif yang diperkenalkan oleh Piaget untuk memberikan gambaran mengenai perkembangan berpikir logis pada siswa dan memperluas gagasan untuk konsep matematika selanjutnya. Dubinsky (2000) mengemukakan bahwa teori APOS adalah teori konstruktivis yang mempelajari bagaimana belajar konsep matematika. Menurut Dubinsky (2000) pemahaman terhadap suatu konsep matematika merupakan hasil konstruksi atau rekonstruksi terhadap objek-objek matematika. Konstruksi atau rekonstruksi itu dilakukan melalui aktivitas aksi-aksi, proses-proses, dan objek-objek matematika yang diorganisasikan dalam suatu skema untuk memecahkan masalah matematika. Teori ini dapat digunakan untuk menganalisis pemahaman konsep dengan cara mendeskripsikan perkembangan skema seseorang pada materi peluang dalam matematika.

APOS telah digunakan secara luas dalam menggali pemahaman siswa melalui tahapan aksi, objek, prores dan aksi. Penelitian yang dilakukan oleh Clark (1997) menggunakan APOS untuk menginterpretasikan tingkat pemahaman mahasiswa tentang konsep dalil rantai. McDonald (2001) menggunakan teori APOS untuk menyelidiki tingkat pemahaman siswa tentang konsep suatu barisan. Widada (2003) menggunakan teori APOS untuk meneliti dan menganalisis pengetahuan siswa dalam menyelesaikan masalah tentang sketsa grafik fungsi dan kekonvergenan barisan tak hingga. Zazkis (1996) menyatakan bahwa kerangka teori APOS telah digunakan untuk menganalisis perkembangan berpikir siswa dalam mempelajari topik fungsi dan grup, serta topik-topik matematika diskrit. Berdasarkan analisis tersebut maka teori APOS dapat digunakan untuk mencari tahu perkembangan pemahaman konsep matematika secara umum. Peneliti dapat menganalisis pemahaman konsep peluang siswa SMP berdasarkan teori APOS.

Penjelasan di atas menyatakan adanya fakta bahwa daya serap materi peluang masih rendah bahkan hasil UN pemahaman konsep peluang rendah dibandingkan implementasinya dalam kehidupan sehari-hari. Kedua masalah ini berkaitan dengan pembentukan konsep materi peluang pada siswa, yang dapat dianalisis menggunakan APOS. Tujuan dari penelitian ini adalah untuk menganalisis pemahaman konsep peluang oleh siswa SMP yang ditinjau dari teori APOS.

\section{METODE}

Jenis penelitian ini adalah penelitian deskriptif kualitatif. Penelitian deskriptif kualitatif merupakan salah satu metode yang digunakan untuk meneliti status kelompok manusia, suatu subjek, suatu kondisi, dan suatu sistem pemikiran (Nazir, 2011) dan dapat digunakan untuk meneliti suatu kondisi objek yang alamiah, dimana peneliti sebagai instrumen kunci, teknik pengumpulan data yang dilakukan dengan triangulasi waktu, dan analisis data bersifat kualitatif (Sugiono, 2012). Sukmadinata (2011) mengemukakan bahwa penelitian deskriptif kualitatif ditujukan supaya dapat mendeskripsikan dan menggambarkan suatu fenomena-fenomena yang ada dan bersifat alamiah maupun rekayasa 
manusia, serta memperhatikan karakteristik, kualitas, keterkaitan antar kegiatan. Penelitian ini termasuk deskriptif kualitatif karena menggunakan narasi, penjelasan tertulis dan gambar-gambar di dalam mendeskripsikan dan menggambarkan cara berpikir siswa dalam memahami materi peluang yang ditinjau dari teori APOS.

Subjek diambil secara purposive. Dan subjek terdiri dari 3 siswa kelas IX SMP N 2 Salatiga yang memiliki kemampuan matematika masing-masing tinggi, sedang, dan rendah. Pemilihan subjek dari nilai kemampuan matematika ini dilakukan berdasarkan data hasil Penilaian Akhir Semester (PAS) 2019 mata pelajaran matematika. Ketiga siswa dipilih dari 27 siswa yang berada pada 1 kelas. Hasil PAS diurutkan kemudian dibagi secara proposional menjadi 5 kategori yaitu kategori tinggi, agak tinggi, sedang, agak rendah, dan rendah berdasarkan banyaknya siswa. Diperoleh siswa berkemampuan matematika tinggi 6 orang, berkemampuan matematika sedang 5 orang, dan berkemampuan matematika sedang 5 orang. Dipilih siswa yang nilainya paling tinggi dalam 1 kelas untuk subjek berkemampuan matematika tinggi, dan siswa yang nilainya berada di tengah untuk subjek berkemampuan matematika sedang, serta siswa yang nilainya paling rendah dalam 1 kelas untuk subjek berkemampuan matematika rendah.

Subjek berkemampuan matematika tinggi adalah SU, subjek berkemampuan matematika sedang adalah NS, dan subjek berkemampuan matematika rendah adalah AZ. Tabel 4 menampilkan rangkuman dari hasil pemilihan subjek.

\section{Tabel 4}

Subjek Penelitian

\begin{tabular}{|c|c|c|}
\hline Subjek & Nilai PAS & Kategori Kemampuan \\
\hline SU & 8.25 & Tinggi \\
\hline NS & 6.25 & Sedang \\
\hline AZ & 2.75 & Rendah \\
\hline
\end{tabular}

Instrumen utama penelitian ini adalah peneliti sendiri dan instrumen pendukungnya adalah soal Tes Kemampuan Matematika (TKM) dan pedoman wawancara. Pedoman wawancara digunakan sebagai pemberi arah dalam penggalian data lebih lanjut sekaligus memeriksa konsistensi data jawaban subjek dari TKM. Soal TKM ini terdiri dari 2 soal berbentuk soal uraian dan cerita dalam kehidupan sehari-hari mengenai materi peluang dasar dan peluang bersyarat. Gambar 1 menyatakan soal TKM.

\section{Selesaikan soal-soal berikut ini!}

1. Ana melemparkan 2 buah dadu secara bersamaan, tentukan peluang kejadian munculnya muka dadu berjumlah 5 !

2. Ani memiliki sebuah kotak yang berisi 3 bola warna merah, dan 2 bola warna kuning. Jika diambil 2 bola secara acak satu persatu berturut turut tanpa pengembalian. Tentukan peluang terambil pertama bola warna merah dan yang kedua bola warna kuning.

Gambar 1. Soal Tes Kemampuan Matematika 
Untuk meguji suatu kredibilitas instrumen maka dilakukan triangulasi waktu. Dalam penelitian ini digunakan triangulasi waktu karena dalam pengujian kredibilitas data dapat dilakukan dengan cara melakukan pengecekan dalam wawancara, observasi atau teknik lain dalam waktu atau situasi yang berbeda (Sugiono, 2008). Instrumen dalam penelitian perlu untuk divalidasi terlebih dahulu. Analisis data yang berbentuk interaktif meliputi tiga hal yaitu reduksi data, penyajian data dan verifikasi (Sutopo, 2003). Pertama adalah reduksi data, pada tahap ini dilakukan setelah mengubah tes wawancara ke dalam bentuk tulisan. Kedua adalah penyajian data yang digunakan sebagai kumpulan dari informasi yang dapat disusun untuk menarik kesimpulan maupun pengambilan sebuah tindakan. Pada tahap terakhir dilakukan verifikasi yaitu pengambilan suatu keputusan atau sebuah kesimpulan mengenai pertanyaan-pertanyaan yang sudah diajukan oleh peneliti kepada subjek

\section{HASIL}

Hasil dari penelitian ini merupakan pemahaman konsep mengenai materi peluang berdasarkan teori APOS pada ketiga subjek penelitian. Berikut merupakan hasil dan analisis penelitian.

\section{Aksi}

Tahap aksi dimiliki oleh ketiga subjek dengan aksi yang berbeda-beda. Aksi pada subjek berkemampuan matematika sedang (NS) dan rendah (AZ) adalah mampu menjelaskan secara verbal mengenai apa yang dimaksud dari soal TKM nomor 1 terlihat pada penjelasan di hasil wawancara AZ yaitu "Tentang Ana melempar 2 dadu secara bersamaan dan menentukan peluang kejadian munculnya muka dadu yang ditentukan, yang ditanya itu peluang kejadian munculnya muka dadu yang berjumlah 5". Aksi NS pada tahap soal nomor 1 yang disampaikan dalam tahap wawancara sebagai berikut "Kalau nomor 1 itu kan Ana melemparkan 2 buah dadu secara bersama-sama. Terus disuruh mencari peluang munculnya muka dadu yang jumlahnya 5 lalu banyaknya yang ditanya dibagi banyaknya yang diketahui semuanya". Pada soal TKM nomor 2 AZ juga memiliki aksi dengan pernyataannya pada hasil wawancara yaitu "Diketahui Ani memiliki sebuah kota yang berisi 3 bola warna merah dan 2 bola warna kuning. Dan yang disuruh menentukan peluang terambilnya pertama bola warna merah dan kedua bola warna kuning".

Subjek berkemampuan matematika tinggi (SU) dapat mencapai tahap aksi pada soal pertama karena mampu menjelaskan secara verbal mengenai apa yang dimaksud dari soal TKM dan pada soal kedua SU mampu menyajikannya dengan situasi matematika. Gambar 2 menunjukkan aksi dari subjek SU yang mampu menyajikan soal TKM ke dalam situasi matematika dengan menuliskan apa yang diketahui dari soal TKM nomor 2.

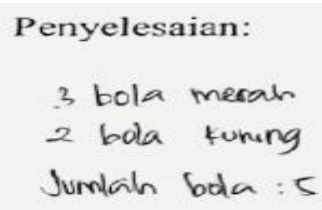

Gambar 2. Aksi Subjek SU 
Jika dilihat dari segi waktu, subjek NS memahami kedua soal dengan waktu 2 menit. Sedangkan SU memahami soal-soal dengan waktu 4 menit dan AZ memahami kedua soal dengan waktu 5 menit.

\section{Proses}

Pada tahap proses subjek mampu mengklasifikasikan objek-objek berdasarkan dipenuhi atau tidaknya persyaratan yang membentuk konsep tersebut. Subjek SU dan NS yang ada di tahap proses. Kedua subjek mempunyai proses yang berbeda namun keduanya mampu memilih cara yang tepat untuk menyelesaikan permasalahan. Subjek SU dapat mencapai tahap proses pada soal pertama karena SU mampu memilih cara yang tepat dalam menyelesaikan soal TKM yaitu dengan menggunakan tabel untuk menentukan titik sampel, SU menuliskan ruang sampelnya terlebih dahulu seperti yang terlihat pada tabel di gambar 3 .

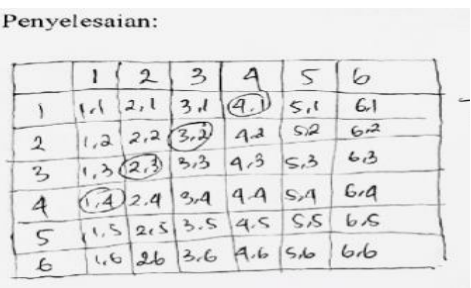

Gambar 3. PROSES SUBJEK SU

$$
\begin{gathered}
\text { Penyelesaian: } \\
1,4 \\
2,3 \\
3,2 \\
4,1
\end{gathered}
$$

\section{Gambar 4. PROSES SUBJEK NS}

Gambar 4 menunjukkan proses dari subjek NS. Tanpa membuat tabel seperti subjek SU, subjek NS langsung menuliskan titik sampelnya. Subjek NS juga mampu menjelaskan langkah awal yang diambilnya dengan menyampaikan pada tahap wawancara sebagai berikut "Pertama kita mencari mata dadu yang berjumlah 5 terlebih dahulu".

Dilihat dari segi waktu NS kembali memilih cara yang tepat dengan waktu yang tergolong singkat yaitu 1 menit. NS mampu mengklasifikasikan objek-objek berdasarkan dipenuhi atau tidaknya persyaratan yang membentuk konsep tersebut

\section{Objek}

Subjek SU dan NS mampu mencapai tahap objek karena SU dan NS mampu menerapkan antar konsep dan prosedur. Pada soal nomor 1 SU dapat menyelesaikan soal peluang dengan metode yang dipilih sesuai penalarannya yaitu dengan tabel lalu melingkari setiap titik sampel yang muka dadunya berjumlah 5 . Kemudian dari banyaknya titik sampel dibagi dengan banyaknya ruang sampel seperti yang terlihat pada gambar 5 .

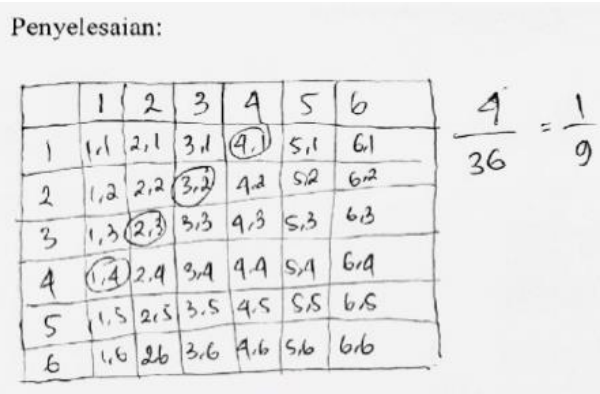

Gambar 5. Objek Subjek SU 
SU mampu menjelaskan setiap langkah demi langkah dalam penyelesaiannya. Dengan menyampaikannya pada tahap wawancara yaitu "Nomor 1 saya membuat tabel, lalu muka dadu berjumlah 5 dibagi semua jumlah yang di tabel”.

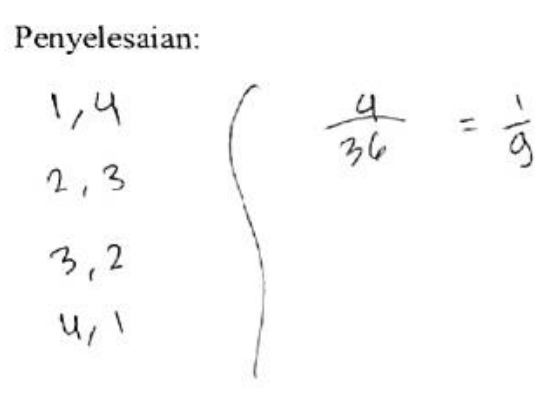

Gambar 6. Objek Subjek NS

Pada gambar 6 NS mengerjakan dengan cara yang sama seperti SU untuk menerapkan antar konsep dan prosedur walaupun langkah awal kedua subjek berbeda tapi hasil akhirnya sama. Diperkuat dengan jawaban NS pada tahap wawancara "Jadi untuk nomor 1 dari banyaknya yang ditanya dibagi dengan yang diketahui totalnya semua, nomor 1 kan hasilnya $\frac{4}{36}$ aku sederhanakan menjadi $\frac{1}{9} "$

\section{Skema}

Subjek SU dan NS mampu mengembangkan konsep yang telah dipelajari. Konsep yang disusun sedikit berbeda karena SU menjelaskan secara terperinci di awal dengan menuliskan terlebih dahulu apa yang diketahui dari soal. Tetapi SU dan NS memiliki kesamaan dalam aksi, proses, objek dan keduanya menghasilkan skema.

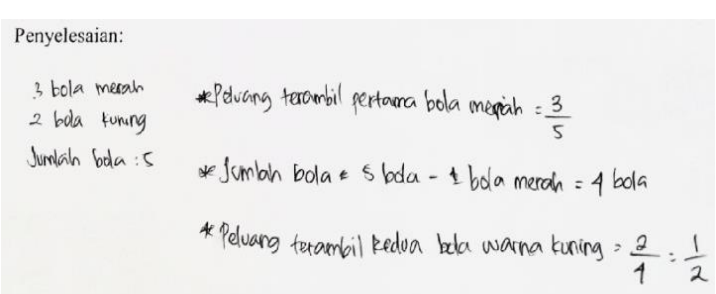

Gambar 7. Skema Subjek SU

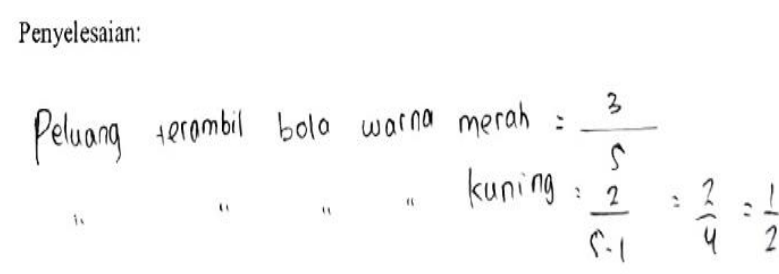

Gambar 8. Skema Subjek NS

Gambar 7, subjek SU menyajikan situasi matematika dan dapat mengembangkan konsep yang dipelajari secara terperinci. Pada gambar 8 subjek NS menuliskan hasil peluang terambil bola warna merah adalah $\frac{3}{5}$ dan peluang terambil bola warna kuning adalah $\frac{1}{2}$ sama seperti hasil dari SU. Sampai di tahap skema subjek NS mengerjakan dengan waktu lebih cepat yaitu 12 menit. Sedangkan subjek SU menyelesaikan dengan waktu 15 menit sampai di tahap skema.

Hasil penelitian menunjukkan aksi dari ketiga subjek yaitu mengetahui tindakan awal untuk menyelesaikan soal peluang dan mampu menjelaskannya secara verbal maksud dari soal tes yang 
diberikan. Subjek berkemampuan matematika tinggi dan sedang menjelaskan secara rinci melalui tahap wawancara sedangkan subjek berkemampuan matematika rendah menjelaskan secara sederhana. Subjek berkemampuan matematika tinggi juga mampu menyajikan dalam situasi matematika.

Subjek berkemampuan matematika tinggi dan sedang mampu mencapai tahap proses dengan mengklasifikasikan objek-objek berdasarkan dipenuhi atau tidaknya persyaratan yang membentuk konsep tersebut. Subjek berkemampuan matematika tinggi menuliskannya dengan membuat tabel terlebih dahulu untuk menentukan ruang sampelnya. Subjek berkemampuan matematika sedang mengerjakannya lebih singkat dengan menuliskan titik-titik sampelnya saja, waktu yang dibutuhkan subjek berkemampuan matematika sedang di tahap proses ini hanya 1 menit.

Pada tahap objek, subjek berkemampuan matematika tinggi dan sedang menyelesaikan soal tes dengan caranya masing-masing. Subjek berkemampuan matematika sedang membagi banyaknya titik sampel dengan banyaknya kemungkinan-kemungkinan yang terjadi saat melemparkan kedua dadu secara beramaan.

Skema yang dimiliki subjek berkemampuan matematika tinggi dan sedang yaitu mampu mengembangkan konsep yang telah mereka pelajari. Subjek berkemampuan matematika sedang mampu menyelesaikan soal TKM dengan waktu tercepat yaitu 12 menit, dan untuk subjek berkemampuan matematika tinggi dapat menyelesaikan soal TKM dengan selama 15 menit. Sedangkan untuk subjek berkemampuan matematika rendah menyelesaiakan soal yang diberikan dengan waktu 23 menit. Subjek yang dapat menyelesaiakan 2 soal TKM dengan jawaban yang tepat adalah subjek berkemampuan matematika tinggi dan sedang. Setiap subjek mengerjakan dengan caranya masing-masing tetapi memiliki hasil akhir yang sama dan benar.

Dari periode 1 dan periode 2 , setiap subjeknya menghasilkan jawaban yang konsisten. Tetapi di periode 2 subjek berkemampuan matematika tinggi mengerjakan dengan waktu yang lebih cepat daripada subjek yang lain, yaitu hanya dengan waktu 10 menit. Dan subjek yang berkemampuan matematika sedang mengerjakan dengan waktu yang sama dari periode sebelumnya yaitu 12 menit dan untuk subjek berkemampuan matematika rendah mengerjakan dengan waktu 20 menit. Dari ketiga subjek yang diteliti, hanya 2 subjek saja yang melakukan aksi, proses, objek, dan skema. Yaitu subjek yang berkemampuan matematika tinggi dan subjek yang berkemampuan matematika sedang.

\section{KESIMPULAN}

Berdasarkan analisis dalam penelitian ini dapat dikatakan bahwa kemampuan hasil belajar matematika siswa mempengaruhi kemampuan pemahaman konsepnya. Siswa dengan kemampuan matematika tinggi mampu menerapkan konsep secara algoritma dengan baik dalam penyelesaian soal, berbeda dengan siswa yang memiliki kemampuan matematika sedang. Siswa yang berkemampuan matematika sedang memiliki skema mampu mengembangkan konsep yang dipelajari. Siswa yang berkemampuan matematika rendah mampu menjelaskan secara verbal apa yang dicapainya. Siswa 
yang memiliki kemampuan matematika rendah harus digali lebih dalam pemahaman konsepnya. Jadi siswa berkemampuan matematika tinggi dan sedang dapat mencapai skema APOS, sedangkan siswa berkemampuan matematika rendah mencapai tahap aksi berdasarkan teori APOS.

\section{DAFTAR PUSTAKA}

Clark, dkk. (1997). Constructing a Schema The Case of the Chain Rule. Journal of Mathematical Behavior. Vol 16 No 4 hal: 345-364.

Dubinsky, dan Fauvel, J. (2000). Teaching and Learning Undergraduate Mathematics.

Dubinsky, E. and M. McDonald, "APOS: A Constructivist Theory of Learning, in Undergraduate Mathematics Education Research", in Holton, D. (Eds.), 2001, TheTeaching and Learning of Mathematics at University Level, Kluwer Academic Publishers, Dordrecht, 275-282.

Matitaputty, C. (2016). Miskonsepsi Siswa dalam Memahami Konsep Nilai Tempat Bilangan Dua Angka. Mosharafa: Jurnal Pendidikan Matematika, 5(2), 113-119, diakses pada 30 Januari 2019

Mulyono, (2011). Teori APOS dan Implementasinya Dalam Pembelajaran. Jurnal Jurusan Matematika FMIPA UNNES, diakses pada 31 Januari 2019

Nazir, M. (2011). Metode Penelitian. Cetakan 6. Bogor: Penerbit Ghalia Indonesia.

Ningsih, Y. L. (2016). Kemampuan Pemahaman Konsep Matematika Mahasiswa Melalui Penerapan Lembar Aktivitas Mahasiswa (LAM) Berbasis Teori APOS Pada Materi Turunan. Edumatica, 6(1), 1-8. https://doi.org/10.1063/1.4944618, diakses pada 28 Januari 2019

Rosmawati, H. (2008). Penggunaan teknik probing untuk meningkatkan pemahaman konsep matematika siswa. Skripsi, Bandung: UPI.

Sholihah, U., \& Mubarok, D. A. (2016). Analisis Pemahaman Integral Taktentu Berdasarkan Teori Apos (Action, Process, Object, Scheme) Pada Mahasiswa Tadris Matematika (Tmt) Iain Tulungagung. Cendekia: Jurnal Kependidikan Dan Kemasyarakatan, 14(1), 125. https://doi.org/10.21154/cendekia.v14i1.551, diakses pada 31 Januari 2019

Sudaryono. (2012). Dasar-Dasar Evaluasi Pembelajaran. Yogyakarta: Graha Ilmu.

Sugiyono. (2012). Metode Penelitian Kuantitatif Kualitatif, dan R\&D. Bandung: Alfabeta.

Sukmadinata, N (2011). Metode Penelitian Pendidikan. Bandung: PT Remaja Rosdakarya.

Widada, W. (2003). Struktur Representasi Pengetahuan Mahasiswa tentang Permasalahan Grafik Fungsi dan Kekonvergenan Deret Tak Hingga pada Kalkulus. Disertasi tidak diterbitkan. Surabaya: Program Pascasarjana UNESA, diakses pada 30 Januari 2019

Zazkis, R and Campbell, S. (1996). Divisibility and Multiplicative Structure of Natural Numbers: Preservice teacher's understanding. Journal for Research in Mathematics Education, 27(5), 540-563 